\title{
The Determinants of Wind Energy Growth in the United States: Drivers and Barriers to State-Level Development
}

\author{
Authors: Kim Schumacher*a, Zhuoxiang Yang ${ }^{\mathrm{b}}$ \\ *akim.schumacher@smithschool.ox.ac.uk, Smith School of Enterprise and the Environment, University of \\ Oxford, South Parks Road, Oxford, OX1 3QY, UK \\ ${ }^{b}$ Graduate School of Arts and Sciences, The University of Tokyo, 3-8-1 Komaba, Meguro-ku, Tokyo 153-8902, \\ Japan
}

\begin{abstract}
The focus of this paper is to analyse the determinants of wind energy development in the United States and how procedural and regulatory frameworks influence the deployment of wind power facilities. The empirical analysis uses statistical regression models integrating geospatial, macroeconomic and socio-environmental control variables. Using wind penetration in addition to wind capacity additions as dependent variable permits a more differentiated analysis of both absolute and relative growth factors. This enables a more precise assessment of state-to-state variations in permitting, zoning and siting procedures that wind developers have to clear before being authorised to start construction. Quantifying the number of state-level financial support measures and various permitting and regulatory process stages allowed for a more comprehensive assessment of administrative barriers to wind energy development than prior research studies. The results indicate a partial reversal of previous findings that showed that a high quantity of state-level regulations negatively affects wind capacity additions. Exogenous factors such as the ratio of in-state federal lands, population density, and especially wind energy potential, as well as federal statutes and incentives remain the main drivers of wind capacity additions and overall wind energy penetration. Contrasting prior literature, the influence of localised financial incentives or regulatory approval procedures appears to be minor; therefore streamlining national policies and incentives at the federal level might prove more effective than promoting wind development at the state level. We also point out that future research should also examine the role of quality of state-level regulations in addition to quantity.
\end{abstract}

\section{Highlights}

- $\quad$ Most up-to-date United States state-level study using recent data sets from 2010-2016 
- Number of financial incentives \& regulatory measures are weak growth indicators

- Overall wind potential is the strongest driver of wind development

- $\quad$ Novel dependent variable for wind penetration enables relative growth analysis

\section{Keywords}

Wind Power; Renewable Energy; United States; Policy; Environmental Regulations; Wind Siting

\section{$\underline{\text { Abbreviations }^{1}}$}

\section{Introduction}

Renewable energy (RE) development has experienced significant growth in recent years in the United States. The majority of this came from the expansion of wind energy, with onshore capacity additions amounting to a $48 \%$ increase from $60,005 \mathrm{MW}$ to $89,078 \mathrm{MW}$ between 2012 and 2017 [1]. Congress has been supporting the transition towards clean and less carbon-intensive energy solutions with several federal measures. Most notably through an industry-wide federal renewable electricity production tax credit (PTC), which has led to a dramatic increase in private-investment driven growth in the wind energy sector $[2,3]$. In light of increasingly deteriorating climate change indicators, RE development has become a core component of most comprehensive greenhouse gas (GHG) emission mitigation scenarios [4].

2016 gained notoriety in recent history as the warmest year on record, accompanied by multiplying indicators of intensifying climatic upheavals, such as the sharp drops of Arctic ice cover [4]. Therefore RE support is considered one of the most effective and efficient strategies against anthropogenic climate change, which threatens numerous ecosystems and vulnerable communities [5]. It represents a strong reduction tool to lower energy-related

\footnotetext{
${ }^{1}$ List of non-standard abbreviations: Bald and Golden Eagle Protection Act (BGEPA), Competitive Renewable Energy Zones' (CREZ) Majority Democratic Representation (DEM), Endangered Species Act (ESA), Energy Policy Act (EPACT), Environmental Regulations (ER), Fixed Effects Vector Decomposition (FEVD) Nr. of State-level Financial Incentives (FI), Ratio of Federal Land Area (FLR), Total State Land Area (LA), Migratory Bird Treaty Act (MBTA), Nr. of State-level Wind Ordinances (ORD), Population Density (PD), Power Purchase Agreements (PPA), Majority Republican Representation (REP), Nr. of State-level Regulatory Measures (RM), Average Distance of State-level wind power capacities to Transmission Lines (TD), Wind Capacities (WC), Wind Development Indices (WDI), Wind Penetration (WP), and Wind Potential (WPT).
} 
output of carbon dioxide and other GHGs into the atmosphere [5]. The $5^{\text {th }}$ Intergovernmental Panel on Climate Change (IPCC) Assessment Report, the Sustainable Development Goals (SDGs) as well as the Paris Climate Agreement have further solidified the importance of shifting away from fossil fuel-based carbon-intensive forms of energy generation towards carbon-neutral renewable energy solutions $[5,6]$.

However, the expansion of RE projects has been facing re-emerging obstacles in some regions, most notably the United States under the revised environmental priorities of the Trump administration [7-9]. This will render efforts to maintain the increase of global temperatures below $2^{\circ} \mathrm{C}$ more challenging [10]. Previous commentators have discussed the prospect of alleviating confrontational trends such as local stakeholder opposition by reducing the number of administrative burdens and barriers, hence allowing the approval and development process to be sped up and become less costly $[11,12]$. This 'green v. green' issue between advocates of GHG emission reductions and those concerned about local environmental impacts such as bat and bird deaths or public health threats like low-frequency noise is at the heart of the ongoing policy debates on what instruments are most suited to expand wind energy while at the same time addressing public concerns [11,12]. As a consequence, the enactment of environmental regulations has become a point for contention of both wind energy development proponents and opponents. The former argue that a panoply of environmental rules and regulations affecting wind will hinder further expansion while the latter contend that these are necessary in light of the potential environmental and socio-economic risks emanating from wind turbines $[11,12]$. This paper will contribute to this discussion by providing the most comprehensive analysis to date of whether the quantity of regulations affecting wind, primarily at the state-level, and to some extent at the county level, significantly influences state-level wind energy growth.

It has already been documented that policies at the federal level act as a major catalyst of comprehensive RE development. A particularly impactful example is the federal production tax credit (PTC) [13]. The latter was originally adopted in 1992 through the Energy Policy Act (EPACT) and is currently set at $\$ 0.023 / \mathrm{kWh}$ for wind, geothermal, closed-loop biomass, $\$ 0.012 / \mathrm{kWh}$ for other eligible technologies, it applies to the first ten years of operation [13]. Previous studies have outlined in detail the preeminent role and influence of this policy tool in increasing deployment of wind energy $[2,14]$. This also inadvertently led to boom-bust cycles that coincided with the respective PTC extensions and expirations $[2,3,15]$ 
However, federal support measures such as the PTC remain the exception and are highly volatile in terms of implementation, with the latter and other federal financial or regulatory measures such as the Clean Power Plan (CPP) either being on halt or subject to revisions. Given the political shifts under the conservative-leaning Congress, the White House, and government agencies, the focus on future state-level wind energy barriers and incentives will become more accentuated $[11,12]$. The absence of comprehensive federal regulatory frameworks is partially offset by state-level rules. However, they do not always define local government powers, which at times results in the development of wind facility projects being stifled due to an unintended regulatory maze created by a lack of uniform procedures and standards [16]. State policies affecting wind energy development show significant variances regarding the structuring of energy policy frameworks and permitting procedures. With many determinants influencing overall RE growth, the objective of this paper is to analyse some of those that face the most criticism among developers. One of these is the number of environmental regulations in the permitting process and siting procedural frameworks such as ordinances [17,18]. Regulations mandating environmental impact statements or imposing stringent rules with regards to rare species protection, environmental health impact considerations, land use or procedural justice can act as barriers to wind energy development [19-22]. Henceforth, they bear the potential to stifle both RE growth and GHG mitigation efforts [19-22].

Therefore, analysing to what extent state-to-state variances in wind energy growth and overall electricity generation share can be attributed to the presence or absence of environmental regulations will permit a deeper understanding of the exogenous factors that impact wind energy development - more specifically large-scale installations - the most and whether or not procedural streamlining reforms of environmental provisions or reductions of regulations could act as a RE support mechanism. In the United States, local zoning laws are one of the primary planning and siting vehicles that determine where installations can be placed [24]. In part to address the public opposition to wind farms due to their proximity to residential areas and to provide clarity to developers, numerous states established clear and uniform wind siting requirements or guidelines instead of delegating it to local authorities $[16,24]$. States thereby adopted two main approaches, falling either into the "Dillon rule" group or the "home rule" group. the "Dillon rule" generally delegates siting authority to state agencies (e.g. public utility commissions or siting councils and boards) often in conjunction 
with local authorities. A majority of states that adopt this approach may limit local authority through state law, such as setting generating capacity thresholds before state regulatory involvement is authorised, for example Washington State [16,24]. In 25 states, the siting of wind facilities requires approval by state or local government bodies depending on size while five states reserve the power to regulate the siting of all wind facilities, regardless of size [16]. The second approach, most often found in "home rule" or "local control" states, cedes siting authority to local governments. In these states, local governments have substantial autonomy to regulate the siting of most wind facilities through their traditional land use authority. Local governments in 20 states have substantial autonomy to regulate the siting of wind facilities, with 15 of those states, including Texas, having no process or legislation specifically addressing wind facilities [16].

Regulatory requirements in the forms of zoning, planning, siting rules constitute fundamental components of wind energy project development. Whether they are performed at the state or county level, several states have begun structured streamlining measures for these procedural steps and centralise them at the state-level [25]. Permitting, zoning, planning and siting are essential elements in assuring that a wind energy project takes account of not only environmental but socio-economic factors as well. This will guarantee that the construction, operation, and the decommissioning of projects occur in the least intrusive manner possible and respect local requirements [25]. With wind resources varying as much within a state as they do across states and zoning laws often being set at the county level, we are attempting to also weigh county-level factors by taking into account these differences through the integration of local ordinances [23]. Ordinances include provisions concerning permits, approvals, operation, and oversight of wind energy installations [26]. We opted for a primarily state-level analysis because under the Trump administration, the importance of state-level action has progressively been increasing especially as tax credits have been reformed and environmental regulatory interventions through federal agencies, most notably the EPA under Scott Pruitt, have decreased [27,28].

This paper addresses these questions through econometric analysis taking into consideration that numerous factors influence state-level installed wind capacity (WC) and wind energy penetration (WP) figures. Therefore a comprehensive overall assessment, of how the number of specific environmental regulatory requirements in state-level wind energy permitting and siting processes contributes to the deployment of large-scale wind energy facilities, will allow 
us to identify any potential correlations between $\mathrm{WC} / \mathrm{WP}^{2}$ and environmental regulations.

Most of the existing literature (see Table 1) deals with the effects of RE policies in general, without any specific focus on wind energy $[31,36]$.

Table 1

Prior literature on econometric research on wind energy determinants

\begin{tabular}{|c|c|c|c|c|c|}
\hline Study & Geography & Method & Dependent Variable(s) & $\begin{array}{l}\text { Main Overlapping Independent } \\
\text { Variables }\end{array}$ & Result ( $\mathrm{S}=$ Significant) \\
\hline$[14]$ & 50 US states & Fixed Effects & $\begin{array}{l}\text { Wind Electricity Deployment } \\
(1990-2011)\end{array}$ & $\begin{array}{l}\text { Renewable Portfolio Standard } \\
\text { (RPS) and GDP }\end{array}$ & S (-) for RPS; S (+) for GDP \\
\hline [29] & 39 US states & $\begin{array}{l}\text { Ordinary Least } \\
\text { Squares (OLS) }\end{array}$ & $\begin{array}{l}\text { Wind Capacity (2003), Wind } \\
\text { Capacity Growth (2000-2003; } \\
\text { 1998-2003), Number of Large } \\
\text { Projects }\end{array}$ & RPS & $\begin{array}{l}\text { S (+) for RPS [Capacity and } \\
\text { Capacity Growth (2000- } \\
\text { 2003)] }\end{array}$ \\
\hline$[30]$ & 37 US states & N/A & Wind Capacity (2007) & $\begin{array}{l}\text { Population, RPS, Wind Energy } \\
\text { Potential, Power Purchase } \\
\text { Agreement (PPA) }\end{array}$ & $\begin{array}{l}\text { S }(+) \text { for Population, Wind } \\
\text { Potential and PPA }\end{array}$ \\
\hline$[31]$ & $\begin{array}{l}122 \text { US } \\
\text { counties; } 46 \\
\text { US states }\end{array}$ & Tobit & Capacity Additions (1998-2007) & $\begin{array}{l}\text { Wind Power Class, Tax Credits, } \\
\text { Transmission Line Coverage }\end{array}$ & $\begin{array}{l}\text { S }(+) \text { for Wind Power Class, } \\
\text { Tax Credits, Transmission } \\
\text { Line Coverage }\end{array}$ \\
\hline$[32]$ & $\begin{array}{l}23 \mathrm{EU} \\
\text { countries }\end{array}$ & OLS & Capacity Additions (2006-2008) & Land area & No documented significance \\
\hline$[33]$ & $\begin{array}{l}132 \text { global } \\
\text { countries }\end{array}$ & $\begin{array}{l}\text { Binary Logit; } \\
\text { Random Effects }\end{array}$ & $\begin{array}{l}\text { Wind power deployment (1980- } \\
\text { 2014) and natural resource } \\
\text { endowment }\end{array}$ & $\begin{array}{l}\text { Quality of wind resources, and } \\
\text { Land Area }\end{array}$ & $\begin{array}{l}S(+) \text { for quality of wind } \\
\text { resources and (-) for Land } \\
\text { Area }\end{array}$ \\
\hline$[34]$ & 48 US states & $\begin{array}{l}\text { Fixed Effects; } \\
\text { Fixed Effects } \\
\text { Vector } \\
\text { Decomposition } \\
\text { (FEVD) }\end{array}$ & $\begin{array}{l}\text { Renewable Energy Electricity } \\
(1998-2006)\end{array}$ & RPS, GDP, and Wind Potential & $\begin{array}{l}\text { S (+) for RPS, GDP and Wind } \\
\text { Potential }\end{array}$ \\
\hline$[35]$ & 39 US states & Fixed Effects & $\begin{array}{l}\text { Carbon Emissions Reductions } \\
(1997-2008)\end{array}$ & $\begin{array}{l}\text { State population, RPS, GDP, } \\
\text { Power Generation (MWh) }\end{array}$ & $\begin{array}{l}\mathrm{S}(+) \text { for GDP and Power } \\
\text { Generation }\end{array}$ \\
\hline
\end{tabular}

Moreover, most of the existing empirical studies concentrate in large parts on individual policies such as renewable portfolio standards (RPS) [34-39] or electricity market regulation elements such as Mandatory Green Power Options (MGPO) [40]. Hitaj [31] does cover a large number of policies at the state and county levels, however environmental components or permitting procedural steps are excluded among that study's independent variables, with most of the focus lying on demographic, macroeconomic or electricity market factors.

Overall, the previous studies presented in Table 1 have established that regulatory measures and financial incentives are, to varying degrees, positively correlated with wind power growth.

\footnotetext{
${ }^{2}$ Throughout the text WC/WP signifies 'WC and WP', not 'WC divided by WP'
} 
Our study does incorporate wind energy data from 38 states covering data for the years 2010 to 2016, allowing for a comprehensive and up-to-date empirical investigation, and thus reflecting recent wind energy developments more aptly. It further builds on the previous literature by analysing the conceptual frameworks and exogenous factors that impact RE development by expanding their geographical scope and temporal reach. Among these case studies, Bird et al. (2005), Menz and Vachon [29], Bohn and Lant [30], Prasad and Munch [35], Brown et al. [41] dealt with wind energy only in a fraction of states, ranging from 12 [37] to $39[29,35]$ and 48 [34] states, whereas the US-level data in the aforementioned studies or Hitaj's [31] does date from 2008 or earlier, thus not taking into account any of the state-level policy developments thereafter. In 2009, a paper by Carley [34] evaluated the effectiveness of state-level RE policies, however without a specific focus on wind energy policies. That study and this paper use a more refined methodology that allows the inclusion of time-invariant factors and time-variant regulatory variables. Fischlein et al. [42] performed one of the few recent wind energy investigations focusing on socio-political state-level factors influencing wind deployment. However, said study does not include any econometric analysis components and is limited to mainly qualitative data analysis, yet it provides some context as to the variances between central and local governance and these could potentially influence wind energy perception and policy-making. In contrast, our paper represents the first comprehensive attempt to measure the influence of siting rules such as in-state wind ordinances in addition to relying on time-variant data for environmental regulations. Hitaj [31] covered only financial incentives while excluding potential regulatory barriers as determinants.

Given the lack of focus on administrative barriers in past econometric studies, this research tries to propose a conceptual framework by determining the overall impact of environmental regulations and procedures on $\mathrm{WC} / \mathrm{WP}$, in order to examine if reducing the number or streamlining environmental frameworks bears the potential to increase the overall share of state-level RE energy [29,34,38,39,43]. Our paper compiles demographic, geographic, geospatial, energy, ecologic, environmental, economic and regulatory data to form an integrated dataset that will then serve as the basis to perform multivariate regression analysis and highlight any potential correlations between wind energy growth and environmental legislation. Our main theoretical assumption is that a high quantity of environmental standards and regulations will lower overall WC/WP rates in states with strong 
environmental protection components in their permitting procedures. Several government bodies and studies have outlined the potentially red tape attributes of an "an unintended regulatory maze created by a lack of uniform procedures and standards" [16,43]. These complexities risk increasing the planning cost and duration for wind energy project developers will incentivise the latter to either abandon development, choose other RE technologies, or engage in development activities in states with little or no regulatory requirements. It should be noted that our study did not consider the quality of the state-level regulatory variables. In absence of a comprehensive qualitative dataset of RE-relevant regulatory frameworks, we opted for quantity of regulations as a proxy to measure the test whether a high number of regulations creates a "regulatory maze" that negatively impacts WC/WP [16,43]. Despite these limitations, this paper still provides the first broad evaluation of wind energy determinants on the US state-level since Hitaj [31] in 2013 and Shrimali et al. [14] in 2015, incorporating recent data as well as novel explanatory variables.

Understanding how environmental regulations impact wind energy development will enable decision-makers and developers to re-assess in what ways regulatory streamlining can contribute to increasing RE growth while still maintaining elevated environmental protection standards. This research is of high relevance, with the Trump administration's ambitions to eliminate as much red tape as possible, which could potentially result in the collateral elimination of numerous environmental regulations in the name of energy development [44]. We pursued a mixed-methodology approach, consisting of a qualitative literature review and quantitative analysis using fixed-effects regression models. We investigated how and to what degree environmental regulations do influence overall environmental growth or if other factors such as geospatial aspects, financial incentives or population dynamics play a more predominant role.

\section{Overview of in-state energy and environmental regulations}

The US represents an interesting case study in that most data is collected nationwide, however, the legal and procedural frameworks sometimes differ significantly from state to state. This allows us to focus on the individual in-state policies affecting wind energy and investigate if a high quantity of environmental provisions in state-wide permitting and siting regulations will notably alter $\mathrm{WC} / \mathrm{WP}$ rates. 
Recent WC/WP rates display at times notable state-to-state variances that can only be partially explained by differing regional wind energy resources, macroeconomic factors, or population dynamics. Environmental impacts on bird and bat populations, low-frequency noise emissions impacts or landscape aesthetics do represent well-documented negative externalities of wind energy installations [45]. Henceforth, environmental legislation subjecting developers to take these incidentals into account, throughout the permitting and siting stages, increases the administrative and financial burdens during the pre-construction planning phases, and generally renders overall investments more risky and expensive [46-48]. In order to assess their impact, we first need to determine which rules affect state-level project development.

In 1969, the United States was the first country in the world to create an integrated legal framework whose sole purpose was the protection of the natural environment. The National Environmental Protection Act (NEPA) mandated that government agencies as well as entities interacting with the government, for example executing government contracts, would have to consider potential environmental impacts prior to the start of any construction activities [49]. They first have to perform an Environmental Impact Assessment (EIA) and produce a comprehensive Environmental Impact Statement (EIS) listing all of the potential socioenvironmental hazards created during the project construction and operation phases [49].

These federal government policies affect state-level wind energy development to a lesser degree, in most instances through projects planned on federal lands. Government agencies including the Bureau of Land Management (BLM), National Forest Service (NFS), Fish and Wildlife Service (FWS), National Park Service (NPS) and the Department of Defense do collectively manage more than 608.9 million acres of land, on which at least 20.6 million acres qualify for wind energy development, mostly in Western Region states such as Nevada, Idaho, Utah or Wyoming [50,51]. As aforementioned, the basic requirements for developers that want to engage in construction activities on these lands is the performance of an EIA followed by the production of an EIS. These projects should influence overall state WC and WP rates only marginally, for example in 2012 total installed capacity of federal lands amounted to just over $800 \mathrm{MW}$ compared to more than $60,000 \mathrm{MW}$ on privately-owned lands [52]. We anticipate that states with high ratios of federal lands might still be negatively impacted given that obtaining development consent for wind energy installations on these 
lands is comparatively much more cumbersome, thus increasing the pressure on privately owned lands to be developed first, potentially forgoing the most promising wind resources.

Notable exceptions of high-impact federal laws are the ones in relation to the protection of certain rare or vulnerable species, in the case of wind energy the most notorious being the Bald and Golden Eagle Protection Act (BGEPA), the Migratory Bird Treaty Act (MBTA) and the Endangered Species Act (ESA) [53]. These statutory provisions apply nationwide, irrespective of activity, property rights or location [54]. Given the fact that these are federal rules, and thus indiscriminate towards state-specific regulatory contexts, they represent only a minor indicator of state-level regulatory variances on wind energy growth potential.

Therefore state-level regulatory frameworks and procedural approval requirements appear to be much better indicators to assess in-state wind energy development potential [30,32]. As aforementioned, numerous states do not have any procedural requirements or central regulatory authorities at the state level and leave the decision-making to local authorities such as counties or municipalities $[16,19,55]$. On the other hand, numerous states implemented environmental rules modelled after the NEPA, which are often designated as "Little-NEPAs" or State Environmental Protection Acts (SEPA) [16,56]. Numerous states also created their own non-NEPA environmental procedural frameworks applicable to wind energy permitting or siting activities $[16,55]$.

Several states created special regulatory procedures for wind energy projects, including Iowa, Vermont, or West Virginia among others; or for energy projects that surpass certain power generating capacities, for example, Oregon for wind generating facilities over $35 \mathrm{MW}$ or New York for facilities over 25MW [16, 55,57]. Given that integrated state-level permitting and siting rules usually facilitate the process for large-scale projects by reducing the number of procedural steps, they can speed up the whole approval process for developers. Several states such as Washington, Hawaii, Colorado or Maine leave the choice up to the developers of large-scale projects whether they prefer local procedures or state procedures, or an appeal to the state level if a permit was denied by local authorities [16,57].

Numerous developers, industry groups, and government agencies cite these environmental provisions as main regulatory barriers deterring wind energy development, with potential investors sometimes abandoning or avoiding projects altogether, due to lengthy, expensive 
and cumbersome EISs and the risk of subsequent nuisance litigation $[47,58]$. Other points of contention are the participatory governance components implemented into these regulations that require a mandatory public consultation phase that enables interested members of civil society and local community stakeholders to voice any potential concerns or objections [59]. The public participation phases follow specific procedural steps, which if not conducted properly, could lead to potential litigation on procedural grounds, which is also decried as a nuisance by many developers and state representatives $[30,47,59]$.

\section{Research Methodology and Data}

We applied an integrated statistical analysis framework to establish correlations between the presence of environmental regulations in state-level permitting and siting procedures and WC as well as WP.

\subsection{Wind Energy Growth Indices}

First modelled and conceptualised after the Wind Development Indices (WDI) in a previous econometric model created by Menz and Vachon [29], we incorporated two dependent variables that measure time variant growth to account for both the installed capacity additions (WC) in each observed state as well as wind penetration, which represents the share of wind energy in state-level electricity generation (WP). These two metrics enable us to identify whether and in what ways WC/WP rates correlate with various factors, particular scrutiny being put on the influence of regulatory frameworks and project approval environments.

We opted for the use of WP in addition to the more generally applied WC to highlight the relative importance of policies at the state level [34]. By focusing on in-state WC and WP, we steer our focus not only on capacity additions but towards the overall contributory role of wind energy in each state as well. To our knowledge, WP has not been integrated into any prior empirical studies in a US context. Given that most prior studies focus on absolute wind capacity growth [29-32], WP does enable a representation of relative growth within statelevel contexts. Albeit US electricity markets enjoy a high degree of interconnection [31], we 
estimate that the juxtaposition of the absolute and relative characteristics of state-level wind energy development will provide additional insights into how state-level policies function if the relative importance of wind in the overall energy mix is accounted for, contrasting previous studies.

Analogous to previous studies [29-31], several states had to be excluded from our analysis due to the absence of exploitable wind resources or notable wind capacities [60]. Albeit in recent years, numerous states in which wind energy development was considered economically unviable for various reasons - for example lack of significant wind resources either added or have seriously been considering adding capacities. These advances have been facilitated by significant technological advances allowing development in areas with low wind speeds. Coupled with increases in local demand or increased stakeholder acceptance, wind energy has progressively been expanding in states like Nevada, New Jersey, Delaware, Connecticut, Vermont and Virginia among others $[1,61,62]$. Otherwise, many projects have not yet materialised as of early 2018 . However, it is anticipated that wind technology innovations will progressively expand the range developable wind energy areas by rendering a more distributed wind development feasible, for example in those states in the East and South East that are currently devoid of any notable wind energy projects [60]. 


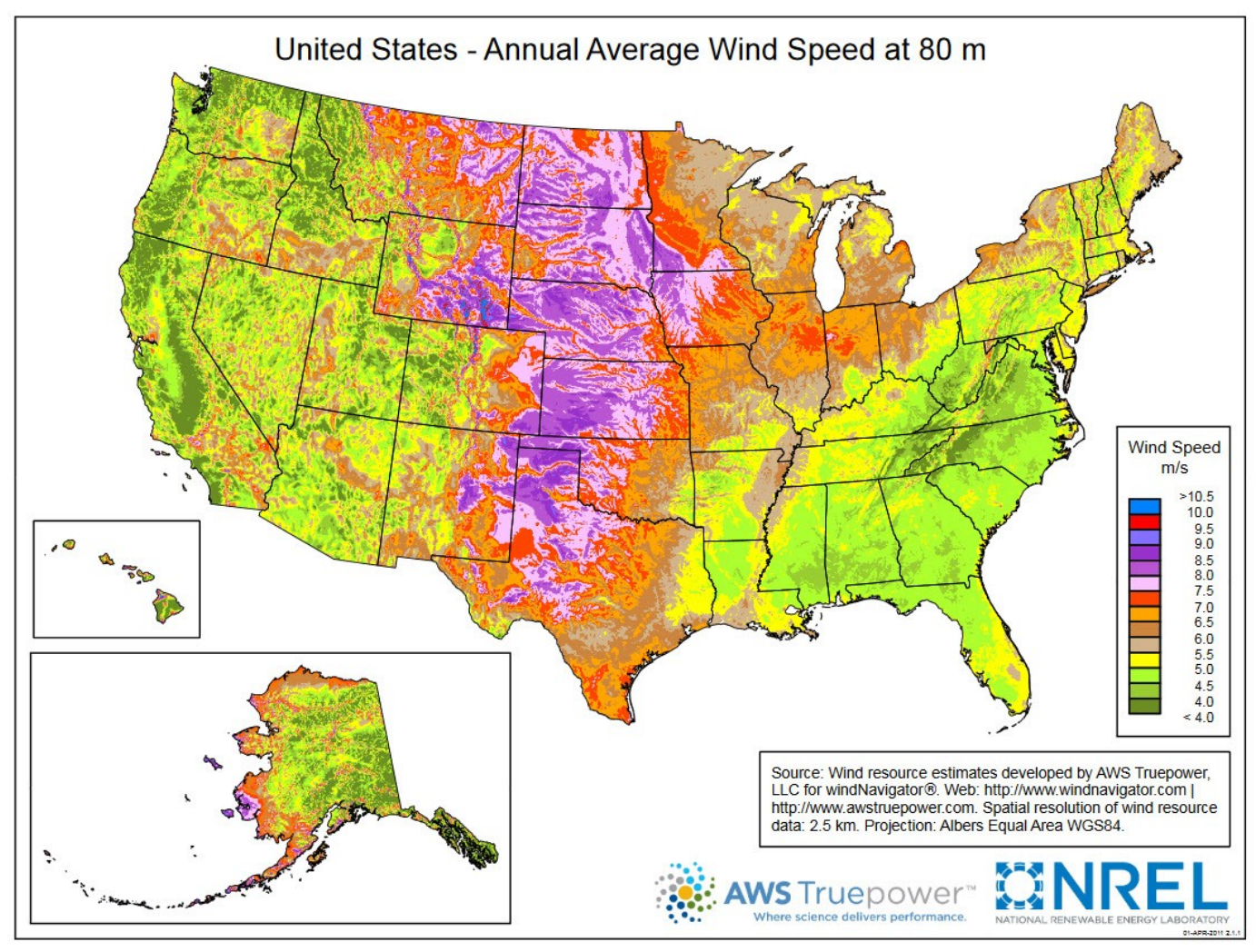

Fig. 1 Annual Average Wind Speed at 80 [63]

\subsection{Determinants of Wind Energy Growth}

To account for the numerous factors impacting growth figures in each state, we used a mix of socio-economic, demographic, geospatial, geographic, environmental, and regulatory variables to analyse their impact on state-to-state WC/WP. By including the determinants presented in Table 2, comprising regulatory body influence, exogenous factors such as $\mathrm{CO}_{2}$ emissions, or an asset-level variable with transmission infrastructure proximity, we obtain a more holistic assessment of the actual project conditions for wind development. As described above, by focusing in-state WC and WP, we analyse not only on capacity additions but the overall contributory role of wind energy in each state as well. 
Table 2

Variables (2010-2016), measurement unit and sources of data for the explanatory variables and expected relationship with dependent variables installed (WC) $[64,65]$ and wind penetration (WP) [66].

\begin{tabular}{|c|c|c|c|}
\hline $\begin{array}{l}\text { Name of } \\
\text { Variable }\end{array}$ & Variable Definition & Source of Data & $\begin{array}{l}\text { Expected Relation with Dependent } \\
\text { Variables }\end{array}$ \\
\hline $\mathrm{CO2}$ & State-level Carbon Emissions (Million Tonnes/ $\mathrm{CO}_{2}$ ) & {$[67]$} & $\begin{array}{l}\text { (-) High levels of } \mathrm{CO}_{2} \text { emissions indicate elevated } \\
\text { levels of thermal energy capacities lowering the } \\
\text { need for additional low-carbon units }\end{array}$ \\
\hline DEM & $\begin{array}{l}\text { Majority Democratic Representation [ } \geq 2 \text { of } 3 \text { state-level } \\
\text { institutions: Governor, State Senate, State House of Reps.] }\end{array}$ & {$[68]$} & $\begin{array}{l}(+) \text { Democratic governments and political majorities } \\
\text { are seen as more progressive towards solutions } \\
\text { addressing climate change mitigation }\end{array}$ \\
\hline FI & Nr. of State-level Financial Incentives Affecting Wind & {$[70]$} & $\begin{array}{l}(+) \text { High numbers of subsidies and tax breaks } \\
\text { considered to spur wind energy development }\end{array}$ \\
\hline FLR & $\begin{array}{l}\text { Ratio of Federal Land Area in Total State Land Area (\% of } \\
\text { State) }\end{array}$ & {$[71]$} & $\begin{array}{l}(+) \text { Development limitations and mandatory } \\
\text { environmental approval regulations on federal land } \\
\text { considered to lower development appeal }\end{array}$ \\
\hline ORD & Nr. of State-level Wind Ordinances & {$[74]$} & $\begin{array}{l}\text { (-) High number of ordinances considered red tape } \\
\text { lowering the appeal of wind energy development }\end{array}$ \\
\hline PD & Population Density (ppl./10km²) & {$[73]$} & $\begin{array}{l}\text { (-) High population density levels increase the risk } \\
\text { of land use conflicts and environmental impact } \\
\text { assessment litigation }\end{array}$ \\
\hline PPA & $\begin{array}{l}\text { Levelised Wind Power Purchase Agreement Prices } \\
\text { (\$cents/KWh) }\end{array}$ & {$[75]$} & $\begin{array}{l}\text { (-) Low purchase power agreement prices increase } \\
\text { the competitiveness of wind energy electricity rates } \\
\text { versus conventional power }\end{array}$ \\
\hline REP & $\begin{array}{l}\text { Majority Republican Representation [ } \geq 2 \text { of } 3 \text { state-level } \\
\text { institutions: Governor, State Senate, State House of Reps.] }\end{array}$ & {$[68]$} & $\begin{array}{l}\text { (-) Republican governments and political majorities } \\
\text { are seen as less progressive towards solutions } \\
\text { addressing climate change mitigation }\end{array}$ \\
\hline WPT & $\begin{array}{l}\text { Wind Potential [Potential installed capacity (MW) } \geq 35 \% \\
\text { GCF } 110 \mathrm{~m} \text { hub height, } 2014 \text { turbine technology (MW)] }\end{array}$ & {$[66]$} & $\begin{array}{l}(+) \text { Presence of high quantity and high-quality wind } \\
\text { energy resources increase wind energy development } \\
\text { potential }\end{array}$ \\
\hline
\end{tabular}

Note: Please refer to Appendix for summary statistics and correlation matrix.

This research considers a novel catalogue of determinants and significantly expands the scope of past studies [30-32,34,38,40]. Previously excluded determinants of potential significance include the ratio of federal land (FLR), time variant environmental regulations (ER) and the number of wind ordinances at the in-state county level (ORD). Hitaj's [31] analysis accounted for transmission line access however, we refined this data component by 
not only calculating overall transmission line coverage per county but by using asset-level data to extract the exact distance between each in-state wind turbine and their proximity to the closest transmission lines. This enables an exact weighting of average transmission line access distance and the probability of general access to state-level grid infrastructure. Hitaj [31] used transmission grid data from 1993; our analysis relied on recent data by the U.S. Department of Homeland Security [77]. This is relevant in terms newly added transmission infrastructure capacities, especially dedicated high-voltage, direct current (HVDC) corridors such as Texas 'Competitive Renewable Energy Zones' (CREZ) transmission lines in the Great Plains region. For all other determinants, the most recent available quantitative data is being implemented, especially in terms of state-to-state WC. Utilising more up to date data figures, precise qualitative measures and quantifying the individual elements of the overall permitting and siting processes, we are able to build upon existing literature and expand the range of our econometric regression model in order to assess in more detail what the impact of procedural frameworks and environmental regulations on wind energy development is.

Geospatial, environmental, and demographic determinants FLR, TD, PD, and WPT are very closely linked to wind energy development, for example indicating the level of potential (see Fig. 1) and overall available resources $[1,78,79]$. Demographic trends in terms such as PD can point to potential land use conflicts or transmission complications caused by the distance of wind facilities from urban consumption centres [78].

Macroeconomic factors GDP and PPA highlight demand-side variations and if wind capacity additions can be absorbed into the market [79]. Production-side measures FI and RPS are expected to influence price formation and render wind energy competitive with existing power generation capacities or future capacity additions from competing energy technologies [79]. Examples of FI include sales, personal and property tax incentives, renewable energy credit programs, utility rate discounts, rebate programs, property assessed clean energy (PACE) financing, loan programs among others [70].

Moreover, we included ER, ORD, $\mathrm{RM}$, and $\mathrm{CO}_{2}$ as controls to point to potential environmental law-related, administrative, or regulatory barriers that could, in large numbers, negatively impact wind energy development. An elevated number of steps in the overall approval process, which is composed of the planning, permitting and siting stages, risks creating an unintended regulatory maze that lacks uniform procedural frameworks $[16,49,79$ - 
81]. Examples of ER include legislation on state-level emission standards, global warming frameworks, or environmental concerns among others [69]. RM controls for regulatory measures meant to create comprehensive frameworks at the state level, examples include the North Carolina or Ohio wind energy permitting standards [70].

Finally, the two political factors DEM and REP account for the impact of governance and political prioritisations on RE development and regulatory environments [82,83]. Menz and Vachon [29] had identified a strong correlation between political interests and green electricity policies, which points to a positive relationship between wind energy development and political decision-making in Democrat-run states as their policies are generally considered more environmentally-friendly [82]. Delmas and Montes-Sancho [40] found significant positive correlations between states that have Democratic governors, representatives, and Mandatory Green Power Option (MGPO) policies, thus further supporting this assumption.

\subsection{Econometric Model}

This article aims to examine the effect of state-level siting and environmental regulatory policies on wind capacity and penetration across 38 states over the period from 2010 to 2016 using standard fixed effects regressions, which is a method for controlling for omitted variables when the omitted variables vary across states but not over time. Fixed effects regression method has the attractive feature of controlling for all stable characteristics of the individuals, whether measured or not. Severe scarcity or absence of exploitable wind energy resources led to the exclusion of 12 states from the estimation sample. Based on the theoretical assumptions and empirical results in prior literature applying various regression models, including ordinary least squares (OLS) or weighted least squares (WLS) among others, we opted for fixed effects and "Fixed Effects Vector Decomposition" (FEVD) models to estimate the effect of regulatory frameworks and environmental policies on wind energy growth $[30-33,84,85]$. We chose the logarithm of wind capacity (WC) and wind energy penetration (WP) as two separate dependent variables, which individually allow us to have a more comprehensive look at multiple wind energy expansion factors [34]. WC/WP were selected because they measure two different factors crucial to understanding the distribution of wind energy. WC indicates the absolute production capacities of wind generation 
infrastructure and WP the share of wind in total state-level electricity generation. In combination with the independent variables, the general forms of the model are as follows:

$\ln W C_{s, t}=\beta_{0}+\beta_{1} P P A_{s, t}+\beta_{2} E R_{s, t}+\beta_{3} G D P_{s, t}+\beta_{4} R P S_{s, t}+\beta_{5} F I_{s, t}+\beta_{6} R M_{s, t}+$ $\beta_{7} C O 2_{s, t}+\beta_{8} O R D_{s, t}+\beta_{9} P D_{s, t}+\beta_{10} T D_{s, t}+\beta_{11} F L R_{s, t}+\beta_{12} D E M_{s, t}+\beta_{13} R E P_{s, t}+$ StateFixedEffects $s_{s}+\varepsilon_{s, t}$

$W P_{s, t}=\beta_{0}+\beta_{1} P P A_{s, t}+\beta_{2} E R_{s, t}+\beta_{3} G D P_{s, t}+\beta_{4} R P S_{s, t}+\beta_{5} F I_{s, t}+\beta_{6} R M_{s, t}+$ $\beta_{7} C O 2_{s, t}+\beta_{8} O R D_{s, t}+\beta_{9} P D_{s, t}+\beta_{10} T D_{s, t}+\beta_{11} F L R_{s, t}+\beta_{12} D E M_{s, t}+\beta_{13} R E P_{s, t}+$ StateFixedEffects $s_{S}+\delta_{s, t}$

where the superscripts $s$ and $t$ denote state and year respectively. $\ln W C_{s t}$ is the logarithm of wind capacity. Explanatory variables are listed in Table 2 and $\varepsilon_{s t}, \delta_{s t}$ are independent and identically distributed error terms.

However, we deem that rarely changing variables such as wind potential and land area play an important role in wind expansion. Fixed effects methods are pretty much useless for estimating the effects of variables that don't change over time, therefore we also use a technique named "Fixed Effects Vector Decomposition" (FEVD) method for estimating time-invariant variables, used in previous RE-related empirical studies [34, 86-88]. In 2007, Plümper and Troeger [85] proposed the FEVD method to deal with time-invariant and rarely changing variables in panel data models with unit effects and demonstrated that FEVD outperforms all the other estimators in estimating models, which suffer from the presence of time-variant variables correlated with unobserved unit effects and time-invariant variables [89]. The FEVD model is based on the standard fixed effects model, and also recognises that some of the fixed individual heterogeneity is in fact observable. The estimations of the corresponding FEVD model are provided as a comprehensive comparison. Otherwise, the effects of such variables will remain included in the fixed effects and are not differentiated.

There are three-stage steps for the estimation of FEVD. First, we run a standard fixed-effects model to obtain unit effects, and then break down the unit effects into a portion explained by time-invariant or rarely changing variables and the error term. Finally, we re-estimate the first stage model with a pooled OLS containing the time-invariant variables and error term of 
stage two [85]. This approach maintains consistency with prior literature for state-level comparisons of energy policy determinants $[34,38,85]$. The fact that FEVD models allow the estimation of variables, which have zero or only small variations, provides us with the possibility to more comprehensively analyse the variables under scrutiny.

\section{Results and Discussion}

Table 3

Regression results with dependent variable: logged WC

\begin{tabular}{|c|c|c|}
\hline Independent variable & Fixed effects & FEVD \\
\hline PPA & $-0.0161(0.001)^{* * *}$ & $-0.0161(0.038)^{* *}$ \\
\hline ER & $0.0256(0.055)^{*}$ & $0.0256(0.131)$ \\
\hline GDP & $0.0739(0.695)$ & $0.0739(0.919)$ \\
\hline RPS & $-0.00298(0.909)$ & $0.120(0.000)^{* * *}$ \\
\hline FI & $-0.0363(0.545)$ & $-0.0363(0.568)$ \\
\hline $\mathrm{RM}$ & $-0.0642(0.224)$ & $-0.0642(0.404)$ \\
\hline $\mathrm{CO} 2$ & $-0.00399(0.036)^{* *}$ & $-0.00399(0.259)$ \\
\hline ORD & $-0.0397(0.136)$ & $-0.0397(0.389)$ \\
\hline PD & $0.00397(0.219)$ & $-0.00119(0.001)^{* * *}$ \\
\hline $\mathrm{TD}$ & $-0.0114(0.000)^{* * *}$ & $-0.0358(0.018)^{* *}$ \\
\hline FLR & $7.913(0.476)$ & $0.805(0.592)$ \\
\hline DEM & $0.0272(0.840)$ & $0.0272(0.883)$ \\
\hline REP & $0.342(0.026)^{* *}$ & $0.342(0.086)^{*}$ \\
\hline WPT & & $0.322(0.069)^{*}$ \\
\hline LA & & $-0.0496(0.094)^{*}$ \\
\hline Constant & $2.02(0.517)$ & $6.99(0.038)^{* *}$ \\
\hline Observations & 264 & 264 \\
\hline R-squared & 0.453 & 0.968 \\
\hline
\end{tabular}

Note: standard errors in parenthesis;

Statistically significant at $* \mathrm{p}<0.1 ; * * \mathrm{p}<0.05 ; * * * \mathrm{p}<0.01$

There is no transmission distance data for State Connecticut and in 2010 and 2011. State Nevada's wind capacity is 0. 
Table 4

Regression results with dependent variable: WP

\begin{tabular}{|c|c|c|}
\hline Independent variable & Fixed effects & FEVD \\
\hline PPA & $-0.000966(0.002)^{* * *}$ & $-0.000966(0.000)^{* * *}$ \\
\hline ER & $0.000633(0.347)$ & $0.000633(0.290)$ \\
\hline GDP & $0.0358(0.097)^{*}$ & $0.0358(0.003)^{* * *}$ \\
\hline RPS & $-0.00364(0.095)^{*}$ & $-0.00364(0.060)^{*}$ \\
\hline FI & $0.000817(0.685)$ & $0.000817(0.750)$ \\
\hline $\mathrm{RM}$ & $-0.00254(0.298)$ & $-0.00254(0.417)$ \\
\hline $\mathrm{CO} 2$ & $-0.000344(0.090)^{*}$ & $-0.000344(0.013)^{* *}$ \\
\hline ORD & $-0.00216(0.212)$ & $-0.00216(0.149)$ \\
\hline PD & $-0.0000432(0.679)$ & $-0.0000432(0.778)$ \\
\hline TD & $-0.000355(0.104)$ & $-0.000355(0.121)$ \\
\hline FLR & $0.991(0.079)^{*}$ & $0.991(0.065)^{*}$ \\
\hline DEM & $0.00244(0.706)$ & $0.00244(0.706)$ \\
\hline REP & $0.00851(0.316)$ & $0.00851(0.300)$ \\
\hline WPT & & $0.0849(0.074)^{*}$ \\
\hline LA & & $-0.0154(0.047)^{* *}$ \\
\hline Constant & $-0.203(0.194)$ & $-0.104(0.570)$ \\
\hline Observations & 266 & 266 \\
\hline R-squared & 0.329 & 0.888 \\
\hline
\end{tabular}

Note: standard errors in parenthesis;

Statistically significant at $* \mathrm{p}<0.1 ; * * \mathrm{p}<0.05 ; * * * \mathrm{p}<0.01$

There is no transmission distance data for State Connecticut.

In Tables 3 and 4, we present the results of the regression analyses. The intrinsic

characteristics and differences in scale and magnitude between WC and WP might partially explain the statistical inconsistencies, which similar results in previous studies confirm $[29,30,32,34]$.

Many previous studies alluded to the potentially stifling effects of excessive state regulation and stakeholder involvement, resulting in burdensome, lengthy, and costly planning, permitting, zoning, and siting processes [21,29,34,38,39]. In addition to the findings of Bohn and Lant [30] about the strong correlation between population dynamics and installed wind energy capacity, our results confirm several past findings for geospatial and demographic (PD, LA), macroeconomic (GDP, PPA), regulatory (RPS) and environmental $\left(\mathrm{CO}_{2}\right)$ factors. However, our findings relativise several prior studies by indicating that the influence of state- 
level regulations and incentives tend to be marginal. No significant relation between WC/WP rates and highly regulated states could be demonstrated. The only state-wide procedural variable that showed any impact was ER with limited significance, thus partially debilitating some of the prior literature [29-31,42,90] that alludes to a significant impact of numerous or lengthy permitting and siting procedures. Despite Del Rio and Tarancón [32] pointing out that the literature is inconclusive as to whether there is a significant relationship between LA and wind capacity additions, our findings reverse earlier findings by Carley [34], reflecting a shift in the US wind energy landscape throughout the past decade in that states with the best wind resources have added significant capacities and were able to increase their in-state $\mathrm{WC} / \mathrm{WP}$, thus more closely reflecting the actual size of their available wind resources. Furthermore, in contrast to a recent study by Gosens [33], a significant positive correlation between WP and WPT has been observed, which confirms that the quality of available wind resources influences state-level wind energy market size.

The results for LA were negative for WC/WP not confirming our initial assumption that states with larger land areas should not only have more available resources but also development appeared to be concentrated mostly in sparsely populated areas such as the Texas or Oklahoma Panhandles, thus lowering the risk of zoning issues [37, 57]. However, these results are fully in line with previous literature that concludes that the importance of overall LA regarding WC/WP largely depends on the quality of the available wind resources $[32-34,87,88]$. Given that the best wind resources often tend to be located in areas with sparse transmission line access, and the significance of TD outlined below, high LA does not automatically translate into high WC/WP for states such Alaska, Texas, Montana, New Mexico, Arizona, Nevada, and Colorado. Also, FLR showed surprising results that did not confirm our original assumption that WC/WP would be negatively correlated. The results preclude our inference that a high degree of federal land would lower the appeal for wind development given that the complex federal regulatory environment, including stringent environmental impact assessments, were expected to act as a barrier. FLR is positively correlated with WC/WP and significant for WP, which can be explained that those states with the highest federal land ratios also tend to have high WPT and low PD. Furthermore, the states that count the most federal land are statistically also the ones with large LA, high WPT, low PD, and REP political majorities at the state government level, which again lowers the risk of encountering zoning issues or stringent environmental regulations [71]. The significant results and strong negative correlations observed for PPA and PD in case of 
dependent variable WC do indicate that low PD and high WPT influence PPA levels, which all are strong determinants of WC, confirming previous findings [30]. The importance of PPA on dependent variable WP is in line with previous study results as well, reinforcing the notion that PPA price levels do reflect not only absolute but also relative in-state wind growth potential [30]. Therefore PPA can be considered a composite factor, taking into account numerous exogenous factors, making it is the most reliable indicator for overall wind development and development potential.

Moreover, the results for TD emphasise and confirm the importance of transmission grid capacities, for example the aforementioned CREZ project in Texas that linked production capacities in the state's sparsely populated Panhandle areas with the more populated regions of North-East and Central Texas [91]. Large-scale transmission projects such as CREZ do play an equally important role as small-scale transmission lines in close proximity to consumption centres as only the large projects enable long-distance connections to remote rural production areas [92]. Transmission issues and the lack of connection opportunities do stifle the development of some of the most promising wind resources, therefore highlighting the importance of grid infrastructure and the proximity of wind energy generation capacities to transmission capacities $[14,31,93]$.

Our findings for ER, RM, and ORD show that those states with numerous regulations do not necessarily lose out on progressive RE development. They are able to cover large portions of their in-state energy demand through wind energy, irrespective of localised supply-side variations caused by procedural barriers or civil society opposition. Our findings partially contravene the significance of regulations as administrative barriers or red tape to wind development, previously described by Del Río and Tarancón, Painuly, the National Conference of State Legislatures, and the National Association of Regulatory Utility Commissioners $[16,32,43,57]$. Past studies $[30,31]$ also showed that some of the advantages of leaving permitting and siting to local authorities would be offset by an elevated number of localised regulations, whereas centralised state-level permitting might eradicate some of these uncertainties through a reduced quantity of procedural steps, streamlined one-stop approaches, more experienced administrators, or access to more extensive resources than local entities.

Our findings for ER, RM, and ORD, however, have only limited explanatory power on $\mathrm{WC} / \mathrm{WP}$ rates and do not confirm this understanding, given that ORD was insignificant as 
well. The results in their current form do not allow us to determine with sufficient certainty whether the states with less designated permitting authorities or fewer specific regulations for wind energy projects do enjoy higher WC/WP. Therefore further in-detail case-study investigations need to be performed on the exact role of "one-stop shop" dedicated administrative procedures and if their presence can result in higher rates of wind deployment. Furthermore, these results show that although there are some correlations between the number of state-level procedural requirements and overall wind energy deployment rates, they remain mostly weak, and thereby indicate a relatively limited impact on state-level WC/WP. The only notable exception is RPS, which confirms the significance of this specific regulatory measure, already illustrated in numerous previous empirical studies [29,37,39]. The results highlight the overwhelming importance of this policy tool, which provides developers and utilities with tangible goals and timeframes that not only lead to capacity additions but render new RE projects economically viable as existing fossil fuel-based thermal capacities need to be substituted through cleaner options. Notwithstanding a few notable exceptions of strongly underperforming (e.g. Nebraska, Missouri and Wisconsin) or overperforming (e.g. Vermont, Maine and Idaho) states, our findings lead us to conclude that both high WC/WP are for the most part linked to exogenous factors of geospatial, demographic, environmental factors and less dependent on state-level regulatory frameworks or financial incentives, contradicting previous literature $[31,36,40]$.

Henceforth, it can be assumed that the impact of specific regulatory components such as environmental or public participation mandates was less influential in states that cover large areas of land, with low overall populations, low population densities, and have high wind potential as well as high degrees of urbanisation. These factors allow for wind to represent more significant percentages of state-level WP, given that projects face less stakeholder opposition and smaller demand-side pressures, thus confirming a strong correlation with PPA. These results stand in contrast with past findings that mention that national or state-level regulatory frameworks and financial incentive mechanisms do play a more significant role than physical energy potential [33]. Recent developments in the domestic wind energy sector have mostly reversed this trend and especially land-rich states with small populations and high WPT, either distributed or localised, were able to develop these sites and reach WP often covering significant portions of in-state energy demand [94]. 
Besides geospatial and demographic factors, the results for FI contradict the previously established correlations between state tax incentives, and more notably tax credits, such as consumption tax credits $[14,31,95]$. FI at the state-level might trigger some leverage in states that already possess an elevated WPT, but they likely will not impact WC/WP in states that have only limited exploitable natural wind resources to begin with, thus partially corroborating previous results [37]. Our results seem to reinforce the overwhelming importance of the aforementioned federal PTC in reducing uncertainty for developers and investors $[14,96]$.

Our results for GDP confirm the results of Carley [34] and Hitaj [31], which show that overall macroeconomic growth can influence WP by stabilising investment environments and demand for electricity projects, however, more pronounced in less populous states, where absolute WC will result in higher overall electricity market share, than in populous states where wind energy started from a smaller baseline. The results for $\mathrm{CO}_{2}$ show a strong negative correlation between overall in-state emissions and WC/WP. Not touched upon in prior wind energy empirical analyses, we suspect that the influence of $\mathrm{CO}_{2}$ emissions is related to the overall state-level macroeconomic condition and the competition between existing thermal energy sources lowering market demand for new capacity additions.

DEM and REP did not reveal any positive development bias towards states with Democratic majorities over the study period, thereby not confirming our original assumption or previous studies pointing to stronger RE growth in jurisdictions with strong environmental voting records, generally associated with the Democratic Party [29,31]. The results interestingly pointed towards a stronger positive WC/WP correlation with Republican-leaning states, which in large parts could be explained with the Republican Party's dominance in rural states, most notably in the Midwest and the Great Plains areas, where most of the wind potential is located, as Figure 1 illustrates [82]. These results are in line with recent research findings and confirm our assumption that LA, WPT and PD outweigh any environmental policy-making, usually considered more progressive in DEM states [72]. Contrasting the view held by Carley [34], our results indicate that state-level political and environmental institutional factors are weak determinants of wind energy, possibly linked to high degrees of endogeneity between REP, WC and WPT [31]. 
Furthermore, our results for ER, RM, ORD, and $\mathrm{CO}_{2}$ suggest that the interplay between environmental factors and the number of environmental regulations seem to have a smaller stifling effect on WC/WP than we anticipated. Examples of such factors include rare species, such as bald eagles or bats, usually considered among the main environmental barriers to wind development [97]. Contrary to prior literature, their interplay with the corresponding environmental protection laws appears to be limited, in that states that show high levels of siting regulations that environmental protection provisions do not necessarily present lower levels of WC/WP [52,98]. Although the BGEPA, the MBTA, and the ESA are federal laws and uniformly applicable in each state, they cannot serve as proof of the stifling effect that environmental regulations were presumed to have at the state level. They might impact development though, especially if states want to develop previously untapped wind resources located on federal lands, making it progressively harder to avoid avian habitats and migratory routes [86]. Given that the aforementioned laws include the species most associated with wind-related animal casualties and the resulting dissuasive effects this can have on developers, it emphasises the continued importance of federal action and how the presence of numerous state-specific regulations appears to have little impact on growth and do not seem to hinder wind energy exploitation as much as previously assumed [99].

Overall, these results overall reinforce our initial assumptions that policy measures and regulatory streamlining efforts have to date been more efficient at the federal level, which has been particularly evident in the case of tax credits, with the federal PTC inhibiting an overwhelming role in supporting wind energy deployment [14]. As the impact of environmental regulations on WC and WP remains limited, cutting their number will not necessarily result in higher wind development rates. These results notwithstanding, statelevel regulations could be reframed to more specifically address wind energy-related issues and support deployment. Localised factors will gain in importance if developable land resources in urban and semi-urban areas will become more scarce and zoning conflicts, between local stakeholders and civil society participants, will emerge over the siting of turbines, and the environmental or aesthetic impacts of wind farms [22]. Several states including Connecticut, New Hampshire, and Ohio - have started to address these issues by assigning siting responsibilities to local governments, with specified content and limits to local regulation, in order to avoid administrative and regulatory inconsistencies [16]. 
We would also like to acknowledge some additional limitations of our study. As outlined above, since our main focus is on state-level regulatory frameworks, the results could be biased by excluding the significance of county-level developments. Second, having used quantity of regulations and incentives does not enable us to estimate the rigidity or quality of regulatory frameworks. The example of the Ohio setback rules, detailed below in section 6 , underlines the importance of performing additional tests including a qualitative measurement of regulations affecting wind. Third, using WP as a determinant does not take account of state-to-state electricity exports, therefore the inclusion of demand-side renewable energy figures would alleviate any production side bias. Fourth, as PPA internalises already numerous exogenous factors, including wholesale market prices as an additional control variable could provide a more comprehensive picture about the influence of price mechanisms on WC/WP.

Therefore, in future research studies, the absence of any comprehensive qualitative datasets for state-level or county-level regulations could be addressed in future research through the production of such a novel dataset. Moreover, a combination of empirical studies using econometric modelling as well as qualitative case study analyses can reveal ways on how to reform and streamline regulatory as well as procedural frameworks. Moreover, they can indicate how to increase WC/WP in more densely populated regions and in close proximity to population centres where more pronounced stakeholder opposition is to be expected. This also applies to areas of high ecological significance such as rare species habitats or migratory bird corridors that could trigger additional zoning conflicts if more wind development and RE deployment are pursued, mainly due to the large land-use footprint of wind farms and other large-scale RE installations [99,100].

\section{Conclusions and policy implications}

The results of our study indicate only limited implications for wind developers through further regulation or increases in RE policies, which might lead to a stronger short-term emphasis on federal measures in the near future. State-wide policies do momentarily appear to impact WC/ WP much less than geospatial and demographic factors. Prior studies indicate that state-level initiatives tend to be more efficient if utilised in combination with the federal PTC [14]. Therefore, data suggest that incentives and policies at the federal level tend to 
influence overall WC/WP to a far higher degree than state-level initiatives [14]. Our observations stand in contrast to previous studies and the strictly localised empirical evaluations therein, which assumed that individual project development was stifled on numerous occasions by a high number of state-level policies and regulations $[46,101]$. Nationwide policies such as the federal PTC or federal environmental protection policies, especially with regards to vulnerable species, largely offset these and thus the overall impact on state-to-state WC/WP rates saw only negligible variances. The results for WP also underline that states with favourable WPT conditions will be the most able to increase their in-state wind energy shares.

However, one should note that in the future, due the political and environmental stances of the Trump administration and its projected decreasing ambition to develop RE sources on federal lands, the conflict potential between local stakeholders and project developers might amplify due to increased land use and siting disputes. In the Western Region states, the elevated ratio of undeveloped federal sites will drive project developers into areas with elevated risks, including more localised adverse environmental impacts, for example proximity to residential areas, resulting in intensifying civil society opposition. Furthermore, ongoing political inactivity in Congress with regards to comprehensive climate change mitigation and RE development policies, as well as and the decrease of comprehensive environmental regulation by federal agencies, such as the Environmental Protection Agency (EPA), will assign an even more prominent role to state-level measures in the future as states will gain more direct influence [7]. Our results for REP do substantiate this assumption because most development potential and wind resources are located in Republican-leaning states $[82,83]$.

In terms of overall implications, given the limited range of our empirical analysis it is important to stress that despite the little general effect on overall $\mathrm{WC} / \mathrm{WP}$ rates, localised state-level effects can differ significantly at times depending on multi-levelised geospatial and socio-environmental factors. To address this particular methodological limitation as well the fact that in numerous states, particularly the aforementioned "home rule" or "local control" states, wind permitting regulations are being developed at the county level, our study should be complemented with a detailed comparative county-level analysis, which could provide additional evidence on how geospatial and regulatory particularities might impact wind energy development. This will matter most in states with less distributed wind resources and 
high population densities, in which potential conflicts might arise due to stringent regulatory frameworks [57]. Figure 2, showing the Midwestern states, illustrates this conflict potential and the corresponding risk to future wind energy development in numerous areas, rendering a stronger influence of ordinances and regulatory measures more probable. For example in Ohio, one of the states having designated a siting board in charge of wind energy regulation, large-scale wind energy development came practically to a halt after the state legislature modified zoning rules and implemented setbacks that require a minimum distance of 1,125 feet from the tip of a turbine's blades to the nearest property line, which in practice means setbacks of about 1,300 feet from each turbine's base [102].
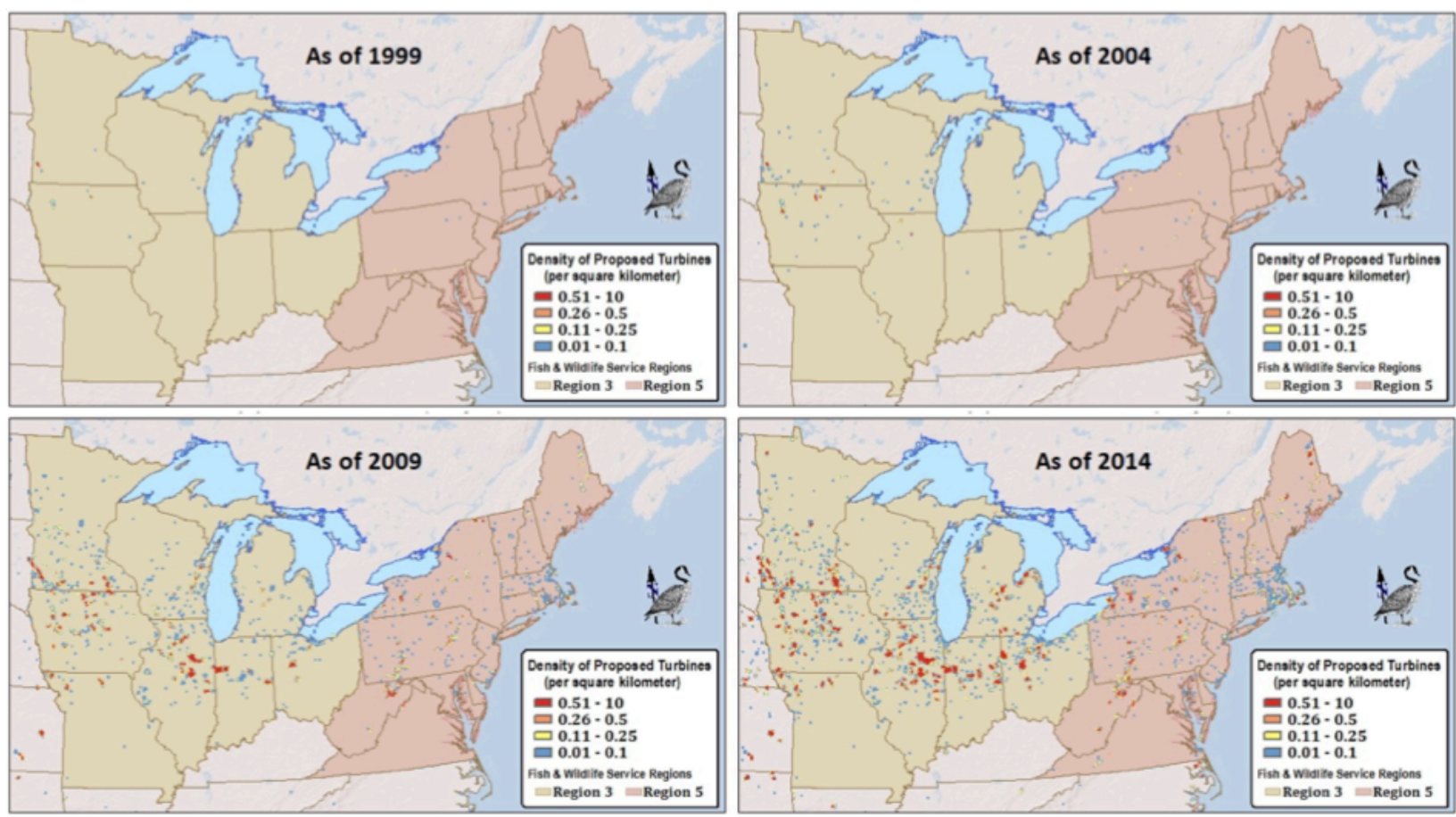

Fig. 2 Evolution of Density of Proposed Wind Turbines (per $\left.\mathrm{km}^{2}\right)$ in North-East and Midwest Region between 1999 and 2014 [103]

These developments align with trends already observed in other states that are either densely populated or where most resources in rural and less contentious areas have already been developed, including Massachusetts, Indiana, Illinois, Wisconsin, Pennsylvania, New York or New Hampshire among others. In these states, land use and zoning conflicts have virtually put a halt on many projects $[58,104-107]$. This did not affect the overall general national 
growth trends, mostly driven by the Great Plains ${ }^{3}$ and Western Region ${ }^{4}$ states where high wind potential coupled with lots of undeveloped land, low population density, and high degrees of urbanisation, prevented many of the land use conflicts observed in other parts of the country $[73,108]$. However, future demographic migratory flows towards the coastlines and growing population concentrations in semi-urban and urban centres risk stifling the development of resources outside of the remote wind energy growth corridors. Expansion will prove extremely challenging, especially without state-level regulatory changes in terms of participatory governance, procedural justice, zoning rules and environmental streamlining $[109,110]$. One example of a state trying to boost WC/WP is Nebraska, which until recently had comparatively low wind development, contrasting the boom experienced in most of the neighbouring Great Plains states such as Kansas, South Dakota [111]. In 2016, state legislators passed LB 824 in an effort to reduce regulations associated with wind energy. As of now, private developers do not require Nebraska Power Review Board project approval anymore; they only need to notify the Board within 30 days of construction to ensure that the project is compliant with all relevant laws and regulations [112].

\section{Acknowledgements}

The authors would like to thank the Ito Foundation U.S.A.-FUTI and MEXT/JASSO for partially funding this research. We also would like to thank the anonymous reviewers for their valuable comments as well as our colleagues at the University of Oxford and the University of Tokyo for their sensible feedback throughout the research and writing stages.

\section{References}

[1] US-DOE, 2017a, Wind Technologies Market Report 2016, U.S. Department of Energy (US-DOE), Washington, D.C., Retrieved from https://energy.gov/sites/prod/files/2017/10/f37/2016_Wind_Technologies_Market_Re port_101317.pdf [accessed 23.12.2017]

\footnotetext{
${ }^{3}$ Great Plains region includes Montana, North Dakota, South Dakota, Wyoming, Nebraska, Kansas, Oklahoma, Colorado, and Texas

${ }^{4}$ Western Region includes New Mexico, Arizona, Utah, Idaho, Nevada, Washington State, Oregon, and California
} 
[2] Lu, X., Tchou, J., McElroy, M.B. and Nielsen, C.P., 2011, The impact of Production Tax Credits on the profitable production of electricity from wind in the U.S., Energy Policy 39, 4207-4214

[3] AWEA, 2015, Wind Energy and the PTC: Sustaining and American Success Story, American Wind Energy Association, Washington, D.C., Retrieved from http://awea.files.cms-plus.com/PTC\%20White\%20Final\%2052115\%20PDF.pdf [accessed 16.10.2017]

[4] WMO, 2016, Provisional WMO Statement on the Status of the Global Climate in 2016: 2016 is set to break even the temperature records of 2015, World Meteorological Organization (WMO), Geneva, Switzerland, Retrieved from http://public.wmo.int/en/media/press-release/provisional-wmo-statement-status-ofglobal-climate-2016 [accessed 14.11.2017]

[5] IPCC, 2014, Climate Change 2014: Mitigation of Climate Change. Contribution of Working Group III to the Fifth Assessment Report of the Intergovernmental Panel on Climate Change (IPCC), In Edenhofer, O., Pichs-Madruga, R., Sokona, Y., Farahani, E., Kadner, S., Seyboth, K., Adler, A., Baum, I., Brunner, S., Eickemeier, P., Kriemann, B., Savolainen, J., Schlömer, S., Von Stechow, C., Zwickel, T. and Minx, J.C. (Eds.), Cambridge University Press, Cambridge, United Kingdom and New York, NY.

[6] IEA, 2016, Energy Technology Perspectives: Towards Sustainable Urban Energy Systems, International Energy Agency, Paris, France.

[7] Zhang, Y. X., Chao, Q. C., Zheng, Q. H., and Huang, L., 2017, The withdrawal of the U.S. from the Paris Agreement and its impact on global climate change governance. Advances in Climate Change Research, 8(4), 213-219

[8] Cardwell, D., The York Times, 2017, Even as Wind Power Rises, It Falls Under a Political Cloud, Retrieved from https://www.nytimes.com/2017/05/30/business/energy-environment/wind-powerbase-load.html [accessed 27.03.2018]

[9] Kariuki, D., 2018, Barriers to Renewable Energy Technologies Development, Energy Today. dx.doi.org/10.1515/energytoday-2018-2302

[10] OECD, 2015, Overcoming Barriers to International Investment in Clean Energy, Organization for Economic Cooperation and Development (OECD), Paris, France

[11] Barradale, M.J., 2010, Impact of public policy uncertainty on renewable energy investment: Wind power and the production tax credit, Energy Policy 38, 7698-7709 
[12] Sneed, A., Scientific American, 2016, Trump's First 100 Days: Climate and Energy, Retrieved from https://www.scientificamerican.com/article/trumps-first-100-daysclimate-and-energy/ [accessed 29.11.2017]

[13] US-DOE, 2016b, Renewable Electricity Production Tax Credit, U.S. Department of Energy, Washington, D.C., Retrieved from http://energy. 2016a gov/savings/renewable-electricity-production-tax-credit-ptc [accessed 18.10.2017]

[14] Shrimali, G., Lynes, M., Indvik, J., 2015. Wind energy deployment in the U.S.: An empirical analysis of the role of federal and state policies, Renewable and Sustainable Energy Reviews. Elsevier. https://doi.org/10.1016/j.rser.2014.11.080

[15] UCS, 2015, Production Tax Credit for Renewable Energy, Union of Concerned Scientists (UCS), Cambridge, MA, Retrieved from http://www.ucsusa.org/cleanenergy/increase-renewable-energy/production-tax-credit\#.WAjJDNyfPXt [accessed 28.10.2017]

[16] NCSL (National Conference of State Legislatures), 2016, State Legislative Approaches to Wind Energy Facility Siting, Washington D.C., Retrieved from http://www.ncsl.org/research/energy/state-wind-energy-siting.aspx\#statutes [accessed 18.3.2018]

[17] Dinnell, A.M. and Russ, A.J., 2007, Legal Hurdles to Developing Wind Power as an Alternative Energy Source in the United States: Creative and Comparative Solutions, Northwestern Journal of International Law \& Business 27(3), 535-590

[18] Slattery, M.C., Lantz, E. and Johnson, B.L., 2011, State and local economic impacts from wind energy projects: Texas case study, Energy Policy 39, 7930-7940

[19] Ottinger, G., Hargrave, T.J. and Hopson, E., 2014, Procedural justice in wind facility siting: Recommendations for state-led siting processes, Energy Policy 65, 662-669

[20] Abbasi, T., Premalatha, M., Abbasi, T. and Abbasi, S.A., 2014, Wind energy: Increasing deployment, rising environmental concerns, Renewable and Sustainable Energy Reviews 31, 270-288

[21] Smart, D. E., Stojanovic, T. A., and Warren, C. R., 2014, Is EIA part of the wind power planning problem? Environmental Impact Assessment Review, 49, 13-23

[22] Le Coz, E., and Sherman, L., 2017, In the Shadow of Wind Farms. Retrieved January 23, 2018, Retrieved from http:/gatehousenews.com/windfarms/home/?skipintro=true [accessed 01.12.2017] 
[23] US-DOE, 2018, Permitting and Zoning, U.S. Department of Energy, Washington, D.C., Retrieved from https://windexchange.energy.gov/projects/permitting [accessed 09.01.2018]

[24] Windustry, Windustry's Community Wind Toolbox, Chapter 5: Siting Guidelines, Minneapolis, MN, Retrieved from http://www.windustry.org/community_wind_toolbox_5_siting_guidelines (accessed 18.10.2016)

[25] Windustry, Windustry's Community Wind Toolbox, Chapter 6: Permitting Basics, Minneapolis, MN, Retrieved from http://www.windustry.org/community_wind_toolbox_6_permitting_basics[accessed 18.3.2018]

[26] SCCCL (Columbia Law School Sabin Center for Climate Change), 2018, Model Municipality Wind Siting Ordinance, Retrieved from http://columbiaclimatelaw.com/resources/model-laws-and-protocols/modelmunicipal-ordinances/model-wind-siting-ordinance/ [accessed 11.4.2018]

[27] Tollefson, J., 2017, Fears rise for US climate report as Trump officials take reins. Nature, 548(7665), 15-16

[28] Plumer, B., New York Times, 2017, Tax Bill Largely Preserves Incentives for Wind and Solar Power, Retrieved from https://www.nytimes.com/2017/12/16/climate/tax-billwind-solar.html [accessed 19.12.2017]

[29] Menz, F. C., and Vachon, S., 2006, The effectiveness of different policy regimes for promoting wind power: Experiences from the states. Energy Policy, 34(14), 17861796

[30] Bohn, C. and Lant, C., 2009, Welcoming the Wind? Determinants of Wind Power Development Among U.S. States, The Professional Geographer 61(1), 87-100

[31] Hitaj, C., 2013, Wind power development in the United States, Journal of Environmental Economics and Management 65, 394-410

[32] Del Río, P. and Tarancón, M.-A., 2012, Analysing the determinants of on-shore wind capacity additions in the EU: An econometric study, Applied Energy 95, 12-21

[33] Gosens, J., 2017, Natural resource endowment is not a strong driver of wind or PV development. Renewable Energy, 113, 1007-1018

[34] Carley, S., 2009, State renewable energy electricity policies: an empirical evaluation of effectiveness, Energy Policy 37(8), 3071-3081 
[35] Prasad, M., Munch, S., 2012. State-level renewable electricity policies and reductions in carbon emissions. Energy Policy 45, 237-242. https://doi.org/10.1016/j.enpol.2012.02.024

[36] Shrimali, G. and Kniefel, J., 2011, Are government policies effective in promoting deployment of renewable electricity resources?, Energy Policy 39, 4726-4741

[37] Bird, L., Bolinger, M., Gagliano, T., Wiser, R., Brown, M. and Parsons, B., 2005, Policies and market factors driving wind power development in the United States, Energy Policy 33, 1397-1407

[38] Yin, A. and Powers, N., 2010, Do state renewable portfolio standards promote in-state renewable generation, Energy Policy 38, 1140-1149

[39] Doris, E. and Gelman, R., 2011, State of the States 2010: The Role of Policy in Clean Energy Market Transformation, National Renewable Energy Laboratory, Golden, CO.

[40] Delmas, M.A. and Montes-Sancho, M.J., 2011, U.S. state policies for renewable energy: Context and effectiveness, Energy Policy 39, 2273-2288

[41] Brown, J.P., Pender, J., Wiser, R., Lantz, E. and Hoen, B., 2012, Ex post analysis of economic impacts from wind power development in U.S. counties, Energy Economics $34,1743-1754$

[42] Fischlein, M., Feldpaush-Parker, A.M., Peterson, T.R., Stephens J.C. and Wilson, E.J., 2014, Which Way Does the Wind Blow? Analyzing the State Context for Renewable Energy Deployment in the United States, Environmental Policy and Governance 24, $169-187$

[43] Painuly, J.P., 2001. Barriers to renewable energy penetration: A framework for analysis. Renew. Energy 24, 73-89. https://doi.org/10.1016/S0960-1481(00)00186-5

[44] House Committee on Natural Resources (HCNR), Trump Administration Slashes RedTape Stifling American Energy Development - House Committee on Natural Resources, Retrieved from https://naturalresources.house.gov/newsroom/documentsingle.aspx?DocumentID=403 833 [accessed 24.7.18).

[45] Dai, K., Bergot, A., Liang, C., Xiang, W-N. and Hunag, Z., 2015, Environmental issues associated with wind energy - A review, Renewable Energy 75, 911-921

[46] Lüthi, S. and Prässler, T., 2011, Analyzing policy support instruments and regulatory risk factors for wind energy deployment-A developers' perspective, Energy Policy $39,4876-4892$ 
[47] Petrova, M.A., 2013, NIMBYism revisited: Public acceptance of wind energy in the United States, Wiley Interdisciplinary Reviews Climate Change 4, 575-601

[48] Troxler, B., 2013, Stifling the wind: California environmental quality act and local permitting, Columbia Journal of Environmental Law, 38(1), 163-195

[49] NEPA (National Environmental Policy Act), 2014, Retrieved from https://ceq.doe.gov/docs/ceq-publications/NEPA_CEQA_Handbook_Feb_2014.pdf [accessed 20.4.2018]

[50] BLM, 2011, 43 CFR Part 2800: Advance Notice of Proposed Rulemaking Regarding a Competitive Process for Leasing Public Lands for Solar and Wind Energy

Development, Federal Register 76(250), Bureau of Land Management, Washington, D.C.

[51] Spengler, E.S, 2011, A shift in the wind: The siting of wind power projects on public lands in the Obama era, Indiana Law Journal 86, 1185-1217

[52] AWEA, 2013, Public lands and wind energy, American Wind Energy Association, Washington, D.C, Retrieved from http://www.awea.org/Issues/Content.aspx?ItemNumber=858 [accessed 13.11.2017]

[53] AFWA and US-FWS, 2007, Wind Power Siting, Incentives and Wildlife Guidelines in the United States, Association of Fish \& Wildlife Agencies, Washington, D.C.; U.S. Fish \& Wildlife Service (FWS), Washington, D.C., Retrieved from https://www.fws.gov/habitatconservation/windpower/AFWA\%20Wind\%20Power\%2 0Final\%20Report.pdf [accessed 17.11.2017]

[54] Panarella, S.J., 2014, For the birds: Wind energy, dead eagles, and unwelcome surprises, Hastings West \& Northwest Journal of Environmental Law and Policy 20(1), 3-50

[55] Geißler, G, Köppel, J. and Gunther, P., 2013, Wind energy and environmental assessments: A hard look at two forerunners' approaches: Germany and the United States, Renewable Energy 51, 71-78

[56] Sive, D. and Chertok, M.A., 2005, "Little NEPAs" and their Environmental Impact Assessment Procedures, ALI-ABA: Environmental Litigation, Retrieved from Www.sprlaw.com/pdf/spr_little_nepa_ali_aba_0605.pdf [accessed 18.10.2017]

[57] NARUC (National Association of Regulatory Utility Commissioners) and Stanton, T., 2012, Put It There! - Wind Energy \& Wind Park Siting and Zoning Best Practices and Guidance for States, Washington D.C., Retrieved from https://pubs.naruc.org/pub.cfm?id=539BA6EE-2354-D714-5157-359DDD67CE7F [accessed 22.10.2017] 
[58] Brown, J.E., 2013, Wind power and nuisance litigation, Defense Counsel Journal 80, 313-321

[59] EPA, 2012, Public Participation: Environmental Impact Assessment in the United States, Environmental Protection Agency (EPA), Washington, D.C., Retrieved from https://www.epa.gov/sites/production/files/2014-05/documents/us-eia-experience.pdf [accessed 6.11.2017]

[60] Baranowski, R., Oteri, F., Baring-gould, I., \& Tegen, S., 2017, Wind Deveopment in the United States: States by Region. Golden. Retrieved from https://www.nrel.gov/docs/fy17osti/67624.pdf [accessed 21.11.2017]

[61] Iberdrola Renewables, 2015, Iberdrola Renewables Files Potential Wind Power Agreement with Green Mountain Power, Retrieved from https://s3-us-west2.amazonaws.com/iberdrola-pdfs/pdf/rel_15.07.02.pdf [accessed 18.10.2017]

[62] Wisniewski, D.J., 2013, The Battle for Wind Farm Siting in Virginia, Virginia Lawyer $63,12-15 \& 41$

[63] NREL, AWS Truepower and US-DOE, 2011, Estimates of Windy Land Area and Wind Energy Potential, by State, for areas $>=30 \%$ Capacity Factor at $80 \mathrm{~m}$, National Renewable Energy Laboratory, Boulder, CO., Retrieved from https://windexchange.energy.gov/files/u/visualization/image/80m_wind_map.jpg [accessed 22.10.2017]

[64] US-DOE, 2016a, WINDExchange: Installed Wind Capacity, U.S. Department of Energy, Washington, D.C., Retrieved from http://apps2.eere.energy.gov/wind/windexchange/wind_installed_capacity.asp [accessed 18.10.2017]

[65] US-DOE, 2017a, U.S. Installed and Potential Wind Power Capacity and Generation, Retrieved from https://windexchange.energy.gov/files/docs/installed_wind_capacity_by_state.xls [accessed 19.11.2017]

[66] NREL and AWS Truepower, 2015, U.S. Installed and Potential Wind Power Capacity and Generation, Boulder, CO. Retrieved from https://windexchange.energy.gov/files/docs/potential_capacity_and_generation_by_st ate.xlsx [accessed 23.11.2017]

[67] US-EIA (Energy Information Administration), 2017, State Carbon Dioxide Emissions Data, Washington, D.C., Retrieved from https://www.eia.gov/environment/emissions/state/ [accessed 16.11.207] 
[68] NCSL, 2017a, State Partisan Composition, Washington, D.C., Retrieved from http://www.ncsl.org/research/about-state-legislatures/partisan-composition.aspx [accessed 23.11.2017]

[69] NCSL, 2017b, Energy and Environmental Legislation Database: Introduced and Enacted Legislation, Washington, D.C., Retrieved from http://www.ncsl.org/research/energy/energy-environment-legislation-trackingdatabase.aspx [accessed 15.12.2017]

[70] Database of State Incentives for Renewables \& Efficiency (DSIRE), 2017, Find Policies $\&$ Incentives by State, Retrieved from http://www.dsireusa.org/ [accessed 04.12. 2017]

[71] Vincent, C.H., Hanson, L.A., Argueta, C.N., Congressional Research Service (CRS), 2017, Federal Land Ownership: Overview and Data, available at https://fas.org/sgp/crs/misc/R42346.pdf [accessed June 5, 2017]

[72] US-BEA, 2015, Broad Growth Across States in 2014: Advance 2014 and Revised 19972013 Statistics of GDP by State, Bureau of Economic Analysis (BEA), Washington, D.C., Retrieved from https://www.bea.gov/newsreleases/regional/gdp_state/2015/pdf/gsp0615.pdf [accessed 24.10.2017]

[73] U.S. Census Bureau, 2016, USA Counties Data File Downloads: Land Area and Population Estimates, Census Bureau, U.S. Department of Commerce, Washington, D.C., Retrieved from http://www2.census.gov/prod2/statcomp/usac/excel/LND01.xls and http://www2.census.gov/prod2/statcomp/usac/zip/PST.zip [accessed 23.11. 2017]

[74] US-DOE, 2017c, Wind Energy Policies and Incentives: Ordinances, Washington, D.C., Retrieved from https://windexchange.energy.gov/policies-incentives\#undefined [accessed 02.12. 2017]

[75] US-DOE, 2017b, Assessing the Future of Distributed Wind: Opportunities for Behindthe Meter Projects, Washington, D.C., Retrieved from https://energy.gov/eere/wind/downloads/2016-distributed-wind-market-report and https://energy.gov/sites/prod/files/2017/08/f35/2016\%20DWMR\%20Data\%20Tables073117.xlsx [accessed 21.11.2017]

[76] LBNL (Lawrence Berkeley National Laboratory), 2017, Renewables Portfolio Standards Resources: RPS Compliance Data, Berkeley, CA, Retrieved from https://emp.lbl.gov/sites/default/files/rps_compliance_data_july_2017.xlsx [accessed 22.11.2017] 
[77] US-DHS (U.S. Department of Homeland Security), 2017, Electric Power Transmission Lines, Washington, D.C., Retrieved from https://hifld-dhsgii.opendata.arcgis.com/datasets/37654d07acfc45689b82fbfc64031d40_0?geometry= $-96.71 \% 2 \mathrm{C} 34.92 \% 2 \mathrm{C}-93.205 \% 2 \mathrm{C} 35.593$ [accessed 14.11. 2017]

[78] NREL, 2018, 2017 State of Wind Development in the United States by Region 2017 State of Wind Development in the United States by Region, National Renewable Energy Laboratory (NREL), Golden, CO., Retrieved from https://www.nrel.gov/docs/fy18osti/70738.pdf [accessed 18.05.2018]

[79] Cox, S., Tegen, S., Baring-Gould, I., Oteri, F.A., Esterly, S., Forsyth, T. and Baranowski, R., 2015, Policies to Support Wind Power Deployment: Key Considerations and Good Practices, Clean Solutions Center, U.S. Department of Energy, Washington, D.C.

[80] Badichek, G., 2016, Resolving Conflicts Between Endangered Species Conservation and Renewable Energy Siting: Wiggle Room for Renewables?, Environmental Claims Journal 28(2), 163-184

[81] Tegen, S., Lantz, E., Mai, T., Heimiller, D., Hand, M. and Ibanez, E., 2016, An Initial Evaluation of Siting Considerations on Current and Future Wind Deployment, National Renewable Energy Laboratory, Golden, CO.

[82] Coley, J. S., and Hess, D. J., 2012, Green energy laws and Republican legislators in the United States. Energy Policy, 48, 576-583

[83] Hess, D. J., Mai, Q. D., \& Brown, K. P., 2016, Red states, green laws: Ideology and renewable energy legislation in the United States. Energy Research and Social Science, 11, 19-28

[84] Vachon, S., and Menz, F. C., 2006, The role of social, political, and economic interests in promoting state green electricity policies. Environmental Science and Policy, 9(78), 652-662

[85] Plümper, T., and Troeger, V. E., 2007, Efficient estimation of time-invariant and rarely changing variables in finite sample panel analyses with unit fixed effects. Political Analysis, 15(2), 124-139

[86] Yi, H. and Feiock, R. C., 2014,, Renewable Energy Politics: Policy Typologies, Policy Tools, and State Deployment of Renewables. Policy Studies Journal 42, 391-415. doi: $10.1111 /$ psj. 12066 
[87] Marques, A.C., Fuinhas, J.A., Pires Manso, J.R., 2010. Motivations driving renewable energy in European countries: A panel data approach. Energy Policy 38, 6877-6885. https://doi.org/10.1016/j.enpol.2010.07.003

[88] Aguirre, M., Ibikunle, G., 2014. Determinants of renewable energy growth: A global sample analysis. Energy Policy 69, 374-384. https://doi.org/10.1016/j.enpol.2014.02.036

[89] Plümper, T., and Troeger, V. E., 2011, Fixed-effects vector decomposition: Properties, reliability, and instruments. Political Analysis, 19(2), 147-164

[90] Schmalensee, R., 2009, Renewable electricity generation in the US, MIT-CEEPR, Cambridge, MA, Retrieved from http://ceepr.mit.edu/files/papers/2009-017.pdf [accessed 18.10.2017]

[91] Malewitz, J., Texas Tribune, 2013, \$7 Billion CREZ Project Nears Finish, Aiding Wind Power, Retrieved from https://www.texastribune.org/2013/10/14/7-billion-crezproject-nears-finish-aiding-wind-po/ [accessed 18.10.2017]

[92] Fischlein, M., Wilson, E.J., Peterson, T.R., Stephens, J.C., 2013. States of transmission: Moving towards large-scale wind power. Energy Policy 56, 101-113. https://doi.org/10.1016/j.enpol.2012.11.028

[93] Fischlein, M., Wilson, E.J, Peterson, T.R. and Stephens, J.C., 2013, States of transmission: Moving towards large-scale wind power, Energy Policy 56, 101-113

[94] Orrell, A., F Foster, N., L Morris, S., and S Homer, J., 2017, 2016 Distributed Wind Market Report. Oak Ridge, Retrieved from http://www.energy.gov/sites/prod/files/2015/08/f25/2014-Distributed-Wind-MarketReport-8.7_0.pdf [accessed 24.11.2017]

[95] Stokes, L. C., and Breetz, H. L., 2018, Politics in the U.S. energy transition: Case studies of solar, wind, biofuels and electric vehicles policy. Energy Policy, 113(November 2017), 76-86

[96] Eryilmaz, D., \& Homans, F. R. (2015). How does uncertainty in renewable energy policy affect decisions to invest in wind energy? Electricity Journal, 29(3), 64-71. https://doi.org/10.1016/j.tej.2015.12.002

[97] Pagel, J. E., Kritz, K. J., Millsap, B. A., Murphy, R. K., Kershner, E. L., and Covington, S., 2013, Bald Eagle and Golden Eagle Mortalities at Wind Energy Facilities in the Contiguous United States. Journal of Raptor Research, 47(3), 311-315

[98] Glen, A. M., Barho, R.D. and Evans, L.M., 2013, How federal wildlife laws impact development of wind energy, Trends 44(4), 14-17 
[99] Trainor, A.M., McDonald, R.I. and Fargione, J., 2016, Energy Sprawl Is the Largest Driver of Land Use Change in United States, PLoS ONE 11(9), e0162269

[100] Ong, S., Campbell, C., Denholm, P., Margolis, R. and Heath, G., 2013, Land-Use Requirements for Solar Power Plants in the United States, National Renewable Energy Laboratory, Golden, CO., Retrieved from https://www.nrel.gov/docs/fy13osti/56290.pdf [accessed 18.11.2017]

[101] Fischlein Miriam, M., Larson, J., Hall, D.M., Chaudhry, R., Rai Peterson, T., Stephens, J.C., Wilson, E.J., 2010. Policy stakeholders and deployment of wind power in the sub-national context: A comparison of four U.S. states. Energy Policy 38, 4429-4439. https://doi.org/10.1016/j.enpol.2010.03.073

[102] Kowalski, K.M., Midwestern Energy News, 2014, Industry: Setback changes will end new wind farms in Ohio, Retrieved from http://midwestenergynews.com/2014/06/19/industry-setback-changes-will-end-newwind-farms-in-ohio/ [accessed 18.10.2017]

[103] US-FWS, 2014, Estimated Wind Energy Development Pressure: 1994-2014, U.S. Fish \& Wildlife Service, Washington, D.C., Retrieved from https://www.fws.gov/radar/windpower/ [accessed 26.10.2017]

[104] Zaltman, A.J., 2013, Obstructions and Opportunities in the Complex World of Massachusetts Onshore Wind Power Development, Journal of High Technology Law 13(1), 215-246

[105] Treppa, H., 2016, Not a huge fan: Deterring the implementation of wind turbines in the Great Lakes, University of Detroit Mercy Law Review 93, 321-351

[106] Hoffman, N.R., 2011, A Don Quixote tale of modern renewable energy: Counties and municipalities fight to ban commercial wind power across the United States, University of Missouri - Kansas City Law Review 79(3), 717-739

[107] Mulvaney, K.K., Woodson, P. and Prokopy, L.S., 2013, A tale of three counties: Understanding wind development in the rural Midwestern United States, Energy Policy 56, 322-330

[108] US-BR (Bureau of Reclamation), 2017, Recreation in the Great Plains Region, Denver, CO, Retrieved from https://www.usbr.gov/gp/recreation/ [accessed 11.11.2017]

[109] Governing, 2011, State-to-State Population Migration, Retrieved from http://www.governing.com/gov-data/census/2010-census-state-migrationstatistics.html [accessed 18.10.2017] 
[110] Governing, 2015, State Migration Rates - Net Totals: 2010-2015, Retrieved from http://www.governing.com/gov-data/census/state-migration-rates-annual-netmigration-by-state.html [accessed 27.10.2017]

[111] Epley, C., Omaha World-Herald, 2017, New developments help Nebraska take advantage of its capacity for wind power, which accounted for more than 10 percent of its energy in 2016, Retrieved from http://www.omaha.com/money/newdevelopments-help-nebraska-take-advantage-of-its-capacity-for/article_74db577f005b-5c98-94fa-7f20622255b2.html [accessed 06.11.2017]

[112] NREL, 2016, State of Wind Development in the United States by Region, Golden, CO., Retrieved from https://www.nrel.gov/docs/fy17osti/67624.pdf [accessed 19.11.2017] 


\section{Appendix A}

Table A.1

List of variables and summary statistics

\begin{tabular}{llllll}
\hline Variables & Mean & Std.Dev. & Min. & Max. & Obs. \\
\hline WC $(\log )$ & 6.194 & 2.003 & 0.693 & 9.919 & 266 \\
WP & 0.061 & 0.071 & 0 & 0.366 & 273 \\
PPA & 41.476 & 24.209 & 0 & 98.404 & 273 \\
ER & 3.941 & 4.768 & 0 & 34 & 273 \\
GDP & 4.939 & 0.868 & 3.409 & 7.348 & 273 \\
RPS & 4.162 & 7.605 & 0 & 46 & 273 \\
FI & 0.41 & 0.795 & 0 & 5 & 273 \\
RM & 0.183 & 0.59 & 0 & 6 & 273 \\
CO2 & 19.774 & 25.115 & 0 & 100 & 273 \\
ORD & 1.165 & 1.604 & 0 & 10 & 273 \\
PD & 812.749 & 1127.41 & 4.806 & 4695.999 & 273 \\
TD & 3.597 & 13.081 & 0.006 & 161.256 & 266 \\
FLR & 0.178 & 0.227 & 0 & 0.81 & 273 \\
DEM & 0.363 & 0.482 & 0 & 1 & 273 \\
REP & 0.425 & 0.495 & 0 & 1 & 273 \\
LA & 20.116 & 24.632 & 0.268 & 147.795 & 273 \\
WPT & 2.515 & 3.467 & 0.015 & 16.568 & 273 \\
\hline
\end{tabular}

Table A.2

Correlation Matrix

\begin{tabular}{|c|c|c|c|c|c|c|c|c|c|c|c|c|c|c|}
\hline & & 1 & 2 & 3 & 4 & 6 & 7 & 8 & 9 & 10 & 11 & 12 & 13 & 1 \\
\hline 1 & PPA & 1.000 & & & & & & & & & & & & \\
\hline 2 & ER & $0.107 *$ & 1.000 & & & & & & & & & & & \\
\hline 3 & GDP & $-0.193 * * *$ & 0.089 & 1.000 & & & & & & & & & & \\
\hline 4 & RPS & $0.191 * * *$ & $0.513 * * *$ & $0.180^{* * *}$ & 1.000 & & & & & & & & & \\
\hline 6 & FI & $0.192 * * *$ & $0.257 * * *$ & 0.022 & $0.251 * * *$ & 1.000 & & & & & & & & \\
\hline 7 & $\mathrm{RM}$ & $0.107^{*}$ & $0.201 * * *$ & 0.000 & $0.311 * * *$ & $0.246^{* * *}$ & 1.000 & & & & & & & \\
\hline 8 & $\mathrm{CO} 2$ & -0.045 & $-0.262 * * *$ & $-0.277 * * *$ & -0.079 & 0.095 & 0.052 & 1.000 & & & & & & \\
\hline 9 & ORD & $0.129 * *$ & 0.079 & 0.037 & $0.168 * * *$ & $0.160 * * *$ & $0.116^{*}$ & $0.120 * *$ & 1.000 & & & & & \\
\hline 10 & PD & $0.159 * * *$ & $0.149 * *$ & $0.368^{* * *}$ & $0.177 * * *$ & $0.107 *$ & -0.009 & $-0.290 * * *$ & -0.088 & 1.000 & & & & \\
\hline 11 & TD & $-0.316^{* * *}$ & 0.052 & $0.254 * * *$ & $-0.109 *$ & 0.008 & -0.006 & -0.061 & -0.077 & $-0.109 *$ & 1.000 & & & \\
\hline 12 & FLR & $0.174 * * *$ & 0.036 & -0.098 & 0.047 & 0.048 & 0.015 & $-0.116^{*}$ & $-0.160 * * *$ & $-0.372 * * *$ & $0.212 * * *$ & 1.000 & & \\
\hline 13 & DEM & 0.054 & $0.365 * * *$ & $0.251 * * *$ & $0.161 * * *$ & $0.224 * * *$ & 0.063 & $-0.261 * * *$ & 0.041 & $0.287 * * *$ & -0.027 & -0.088 & 1.000 & \\
\hline 14 & REP & $-0.100^{*}$ & $-0.301 * * *$ & $-0.135^{* *}$ & $-0.201 * * *$ & $-0.118^{*}$ & -0.028 & $0.323 * * *$ & 0.013 & $-0.392 * * *$ & 0.050 & 0.057 & $-0.648 * * *$ & 1 \\
\hline
\end{tabular}

